\title{
CLIMATOLOGY OF THE HUMAN THERMAL COMFORT ON SÃO PAULO METROPOLITAN AREA, BRAZIL: INDOORS AND OUTDOORS
}

\author{
Anderson Spohr Nedel ${ }^{1}$, Fábio Luiz Teixeira Gonçalves², \\ Celso Macedo Junior ${ }^{2}$ and Maria Regina Alves Cardoso ${ }^{3}$
}

\begin{abstract}
The purpose of this study is to carry out a climatological analysis of human thermal comfort in the São Paulo city, Brazil, for outdoor and indoor environments, applying different indexes of thermal comfort in order to assess which of them represent best the weather characteristics of the São Paulo city. The relationship between these indexes and the seasons (fall, winter, spring, summer) was investigated in the period from 1980 to 2005, for outdoor environments, and during 2005, for the indoor environments. The results showed that the most appropriate index for São Paulo, both for internal and external conditions was the Effective Temperature Index (ET) as it has a broad classification and can provide appropriate representations of the region's comfort. According to this index, the mornings during summer in the outdoor environments showed mild discomfort by cold, and the afternoons were comfortable. In winter, there was thermal stress by cold during the mornings and a slight discomfort by cold during the afternoons. For indoor environments in the summer, most of the houses presented comfortable mornings, and afternoons with discomfort in relation to the heat, while in the winter, period proved to be uncomfortable and stressful due to cold and the afternoons characterized themselves as comfortable.
\end{abstract}

Keywords: thermal sensation, biometeorology, biometeorological indexes.

RESUMO. 0 objetivo deste estudo é realizar uma análise climatológica do conforto térmico humano na cidade de São Paulo, Brasil, para ambientes externos e internos, aplicando diferentes índices de conforto térmico, a fim de avaliar qual deles melhor representa as características climáticas da cidade de São Paulo. A relação entre esses índices e as estações do ano (outono, inverno, primavera, verão) foi investigada no período compreendido entre 1980 e 2005 para os ambientes externos, como também durante 0 ano de 2005 para os ambientes internos. Os resultados mostraram que o índice de Temperatura Efetiva (TE) é o mais apropriado para São Paulo, tanto para condições internas quanto externas, pois este possui uma classificação ampla e pode fornecer representações adequadas do conforto da região. Segundo esse índice, as manhãs, durante o verão nos ambientes externos, apresentaram leve desconforto por frio, e as tardes estiveram confortáveis. Já no inverno, observou-se estresse térmico por frio durante as manhãs e um ligeiro desconforto por frio no período das tardes. Para os ambientes internos, a maioria das casas apresentou no verão manhãs confortáveis e tardes com desconforto em relação ao calor; já no inverno, o período das manhãs mostrou-se desconfortável e estressante devido ao frio e as tardes caracterizaram-se como confortáveis.

Palavras-chave: sensação térmica, biometeorologia, índices biometeorológicos.

\footnotetext{
${ }^{1}$ Universidade Federal de Pelotas, Faculdade de Meteorologia, Campus Universitário s/n, P.0. Box 354, Pelotas, RS, Brazil. Phone: +55(53) 3275-7328 - E-mail: anderson.nedel@ufpel.edu.br

2Universidade de São Paulo, IAG-USP, Departamento de Ciências Atmostéricas, Rua do Matão, 1226, Cidade Universitária, 05508-090 São Paulo, SP, Brazil. Phone: +55(11) 3091-4704 - E-mails: fabio.goncalves@iag.usp.br; macedo@model.iag.usp.br

${ }^{3}$ Universidade de São Paulo, Departamento de Epidemiologia, Faculdade de Saúde Pública, Av. Dr. Arnaldo, 715, 01246-904 São Paulo, SP, Brazil. Phone: +55(11) 3061-7710 - E-mail: rcardoso@usp.br
} 


\section{INTRODUCTION}

The thermal acceptability of an environment and the perception of comfort or discomfort are related to the production of heat by the body's metabolism, which is transferred to the environment in order to maintain vital body function, resulting in a psychological sensation and a body temperature. This transferred heat is influenced by environmental factors such as air temperature, thermal radiation, humidity and air speed. Also important are the personal factors, such as type of physical activity and type of clothing. A person is thermally comfortable, when all the heat produced or gained by the human body is equal to the amount of heat lost to the environment, by the same body and in the same proportion, so the body maintains an energy balance. The feelings of comfort varies from person to person, therefore, each person reacts differently in relation to the weather and climate. According to ASHRAE (American Society of Heating, Refrigerating and Air-Conditioning Engineers), the definition of thermal comfort would be "the condition of mind that expresses satisfaction with the external environment". The issue of human thermal comfort involves many factors and variables (individual and environmental), becoming an extremely complex matter, variable from individual to individual. In order to estimate the combined effects of meteorological factors on various physiological stimuli, many research works have entered the biometeorological indexes that express mathematically the thermal stress and physiological response of the human body in a given environment.

Since the earliest days of human history, the interest of understanding or by necessity, or curiosity, the relationship between the different weather conditions and human body's physiological response to these changes has always existed. Hippocrates, in his book "Air, Waters and Places", of about 400 BC, described qualitatively the main variables that affect significantly the thermal comfort: temperature, winds, relative humidity and radiation; moreover, provided biometeorological advice for future doctors (cited by Monteiro \& Alucci, 2005). In the seventeenth century, the first measurements of air temperature were held in Florence and Beijing, however, if they wanted to seek views on thermal sensations of certain environments, those were considered vague. In early nineteenth century there were some preliminary studies investigating the influence of thermal stress in the textile industry workers who had health problems (Koenigsberger et al., 1977, cited by Monteiro \& Alucci, 1996).

Only in the twentieth century, however, the first scientific researches related to human thermal comfort emerged. Houghten \& Yaglou (1923) proposed the Effective Temperature Index, that considerated the aggregate effects of variables air temperature and relative humidity, as psychological responses to sensations experienced by people. Currently, among the most recent studies include Olgay (1992) that in the years 1960 proposed a definition for the environmental thermal comfort. Different areas of comfortable temperatures for various climates were identified, such as: U.S., between $23^{\circ} \mathrm{C}$ and $27^{\circ} \mathrm{C}$; England, from $14^{\circ} \mathrm{C}$ to $21^{\circ} \mathrm{C}$; $23^{\circ} \mathrm{C}$ to $24^{\circ} \mathrm{C}$ for the tropics.

Maia (2002) analyzed the human thermal comfort during the year 1989 in the city of São Paulo, and evaluated the influence of one or more meteorological factors on the population (daily hospital admissions for respiratory diseases and air pollution). He used five biometeorological indexes, and applied them to a given sample of the city's population. The results showed that the average hospital admissions for 1989 were associated with meteorological parameters, levels of air pollution, and the indexes of human thermal comfort. Braun (2003) examined the human thermal comfort in the city of São Paulo during the period 1996 to 2000 and the related behavior of certain biometeorological indexes, of meteorological variables and levels of air pollution with cardiovascular disease in people over 65 years. The results showed the period of the summer as the biggest influence to the condition of thermal stress in due to heat. When the author related the mortality rate for this population sample to the weather conditions, he found that the conditions related to cold were responsible for $45 \%$ of deaths in the city of São Paulo, while weather situations related to heat accounted for $24 \%$ of deaths.

As we spend approximately $90 \%$ of our lives indoors, a good understanding of thermal conditions found within such environments is natural and very important. In that sense, many studies have been made taking into account not only the physical variables of the environment, but the characteristics of buildings and behavior of their occupants. Such variables associated with the development of empirical formulas, represented in the form of biometeorological indexes, can express numerically the degree of thermal satisfaction or dissatisfaction (though empirically) of a given environment. The degree of thermal comfort (indoors) of these environments could, for example, be estimated through internal measures of some variables such as air temperature and relative humidity, which added up to the wind, could be crucial for physiological, psychological and biological sensations felt by the human body, and may well change their daily behavior.

The ASHRAE (American Society of Heating, Refrigerating and Air-Conditioning Engineers), referential organization when it comes to conditions for thermal comfort, set national standards for human occupation in indoor environments. This standard, called Standard 55-1992, describes experiments based on 
areas of thermal neutrality. The proposal is to specify a combination of an indoor environment and personal factors, which could produce thermally acceptable conditions (thermal comfort), for at least $80 \%$ of the occupants of a particular place, (ASHRAE, 1992). These conditions are designed to healthy people, from the surface to an altitude of 3000 meters for human occupation and periods of stay longer than 15 minutes, still, according to ASHRAE. Analyzing popular houses, Viamont (1996) verified the quality of thermal comfort of homes in a settlement in Cochabamba, Bolivia. The effect of external temperature has been studied in homes to determine optimal parameters of comfort and standards of construction, to reduce the discomfort caused by high and low temperatures. He noted that the thermal comfort can be improved if some characteristics of housing were modified, among them: ceiling with low thermal conductivity; more ventilation in summer and infiltration control during the winter; use of bright colors on the walls, causing high-reflection during the summer.

The influence exerted by occupants in thermal performance in office buildings naturally ventilated was studied in Oxford and Aberdeen, UK, (Givoni, 1994). In offices where the occupants have full control of the environment (open windows, shutters, curtains, etc.), they played an important role in changing conditions internally observed. According to the author, although the residential and office buildings have different uses, occupations and internal gain, the way the occupants use the environment may modify its thermal performance and achieve the thermal comfort.

Givoni (1999) monitoring small households (not conditioned) in the town of Pala, southeast of California, USA, has developed simple formulas using a minimum amount of external climate information to estimate the internal temperature of their environments. When these homes were cooled by nocturnal ventilation and remained closed during the day, the maximum internal temperature, for example, could be predicted taking as a basis only average external temperature. Givoni \& Vecchia (2001) describe a methodology for estimating temperatures (maximum, medium and minimum) internal daily, in homes in the city of Descalvado, Brazil. The formulas used were developed based on data collected in September 2001 and validated through a comparison with data collected in the months of November and December of that year. It was found that the internal temperature maximum, medium and minimum, could be estimated using the daily average of the external temperature. They also concluded that the prediction of indoor temperatures, maximum and minimum can be slightly improved by incorporating the average daily balance of sunlight and the daytime temperature, respectively, to the formula.
Papst \& Lamberts (2001) analyzed the thermal performance of homes in the city of Florianopolis, southern Brazil. They observed three different homes and monitored their daily internal temperatures between April 1998 and May 1999. They compared the behavior of these temperatures and correlated it with the daily average outside. The results showed that the use of the environment by its occupants, the characteristics of households and the external weather conditions were decisive factors for the thermal performance analysis of the homes. In another study involving the thermal performance of occupied buildings, Krüger \& Givoni (2003) analyzed three popular residences of different constructive types in the city of Curitiba, Brazil, without any kind of internal conditioning. Then, they monitored the houses in periods (several days) of summer and winter, and the daily values observed in the three homes were compared to the values obtained by applying estimative formulas of internal temperature (minimum and maximum) and values simulated by the software (COMFIE). The results showed for the three homes, that the minimum internal temperature showed the highest correlation between observed and calculated values of temperature, with $\mathrm{R}^{2}=0.99$. The lowest correlation was found with the internal temperature maximum, with an average $\mathrm{R}^{2}=0.9588$. Still according to the authors, "if there is any experimental representative data of the internal and external conditions, measured over several weeks, it will be possible to estimate the thermal performance of a building (residence), for any kind of weather".

Relating the exposure of children and the indoor climate, Nafstad et al. (2005) studied the relationship between the exposure of children between three and five years old in "hospitals" and respiratory problems, possibly attributed to humidity. From 175 hospitals analyzed in the study, $51 \%$ had a problem of humidity inside it (infiltration from the ceiling or walls, leakage of water). Through an analysis of multiple logistic regression with the hospitals, it was found that none of the diseases or respiratory symptoms studied were associated with problems of humidity, or type of existing ventilation inside.

Considering that most of our lives (approximately 90\%) is spent in indoor environments (Sundell, 1999), and that a small portion is devoted to outdoor environments, this study aims to carry out a climatological analysis of various indexes of human thermal comfort in outdoor environments in the metropolitan region of São Paulo. This study aim to carry out a climatological analysis of human thermal comfort in the city of São Paulo, for outdoor and indoor environments, and so establish a thermal comfort index to characterize the most realistic possible way the weather conditions that impact on human health. The most 
typical indexes of thermal comfort for MRSP was applied to outdoors and indoors environments, that is, also inside homes of MRSP - within scope of the Wheezing Project - that examines the influence of air pollution generated by the traffic of vehicles, and its interaction with the adverse environmental and weather conditions, in the development of diseases, respiratory infections, allergy and atopic sensitization in children with a family history of asthma, residents in the city of São Paulo.

\section{MATERIALS AND METHODS}

The Metropolitan Region of São Paulo (MRSP) is geographically situated in the southeast portion of Brazil with an area of $8000 \mathrm{~km}^{2}$ and a population of approximately 17 million inhabitants, which represents the third largest urban agglomeration in the world. Outlined by the Mountain Range of the Sea (Serra do Mar), its topography is dominated by hills and mountains that range from 650 to 1200 meters high. The climate of the MRSP is considered subtropical (Cwa type, Köppen classification), with annual average temperature of $19.3^{\circ} \mathrm{C}$ (IAG/USP station, normal from 1980 to 2007) and average temperatures during winter of $16^{\circ} \mathrm{C}$ and of $22^{\circ} \mathrm{C}$ during summer. Due to its proximity to the Atlantic Ocean (60 $\mathrm{km}$ away) the region is influenced by the effect of sea breeze that is a constant in the local weather (Oliveira \& Silva Dias, 1982). The average annual precipitation is $1317 \mathrm{~mm}$, according to Instituto de Astronomia, Geofísica e Ciências Atmosféricas station, of the Universidade de São Paulo (IAG/USP) that may be divided into two main seasons: a rainy season which includes the period from October to April and another dry season that goes from May to September. The rainy season is influenced by continental warming, which, associated with cold fronts and areas of instability, beyond urban heat island effect of the city, favor the occurrence of abundant rainfall in the region. The dry season is characterized by having winters with high concentrations of pollutants, influenced by the predominance of highpressure systems on the region.

\section{Climatological data}

The meteorological data used to represent the outdoor environment were obtained from the meteorological station of the State Park (IAG/USP), located in the neighborhood of Água Funda, southern city of São Paulo, 2337'S, 46 ${ }^{\circ} 37^{\prime} W$. Daily average data of maximum and minimum temperature variables were acquired, as well as wind speed, relative humidity, maximum and minimum, for the period from 1980 to 2005. The next stage was to compile such daily average data in order to see in which range these values were found and thus verify which indexes of comfort, suggested by the literature (Maia 2002; Braun, 2003; Gonçalves et al., 2007) would be more suitable for thermally represent the MRSP. The representative meteorological variables of the indoor environment were obtained through experimental campaigns, inserted into the "Wheezing Project"; carried out within 426 homes in the city of São Paulo (Fig. 1). Measurements were made in the child's bedroom, with an analog Temperature/Humidity Datalogger, Oakton brand, model 08369-70, for a period where one day is 24 hours of observation - in this paper will be presented the measurements for all seasons of the year 2005.

\section{Thermal comfort index}

To assess the thermal perception of the outdoor environment in the MRSP, three indexes of thermal comfort were used: Discomfort Index, DI (Thom, 1959); Effective Temperature Index, ET (Missenard, 1937); and Effective Temperature Index according to the wind, $E T_{w}$ (Suping et al., 1992). For the calculation of these indexes, three different combinations have been used: temperature and average humidity, situation (1); maximum temperature and relative humidity minimum, situation (2); minimum temperature and relative humidity maximum, situation (3). The insertion of these three situations is needed considering the extreme conditions that affect in more pronounced way the thermal sensations of the environment (outdoor), represented daily. To check the indoor environment behavior, the Effective Temperature Index (ET) was considered to assess the thermal conditions experienced in those environments. Thus, the average wind was not considered in the calculation, because wind speed inside the residences (child's bedroom) is very low, or nonexistent. In this environment, the collection of data of meteorological variables air temperature and relative humidity, were held inside of 180 residences in 2005, counting 1098 days with measures ( six days in each residences). These homes are mostly located in the north and west areas of the city and the measurements were made with an analog Temperature/Humidity Datalogger, Oakton brand, model 08369-70, for a period where one day is 24 hours of observation (Figs. 1 and 2). The samples were collected in the homes of newborn children, residents in the city of São Paulo, who had a family history of asthma. The instrument was installed in the child's bedroom (often in the mother's), that is, in the place where the child slept. After collecting data, the calculation of the thermal comfort Effective Temperature Index (ET) was done, for the different residences sampled and measured in the same period of time, in order to express and evaluate (although that empirically) the internal thermal 


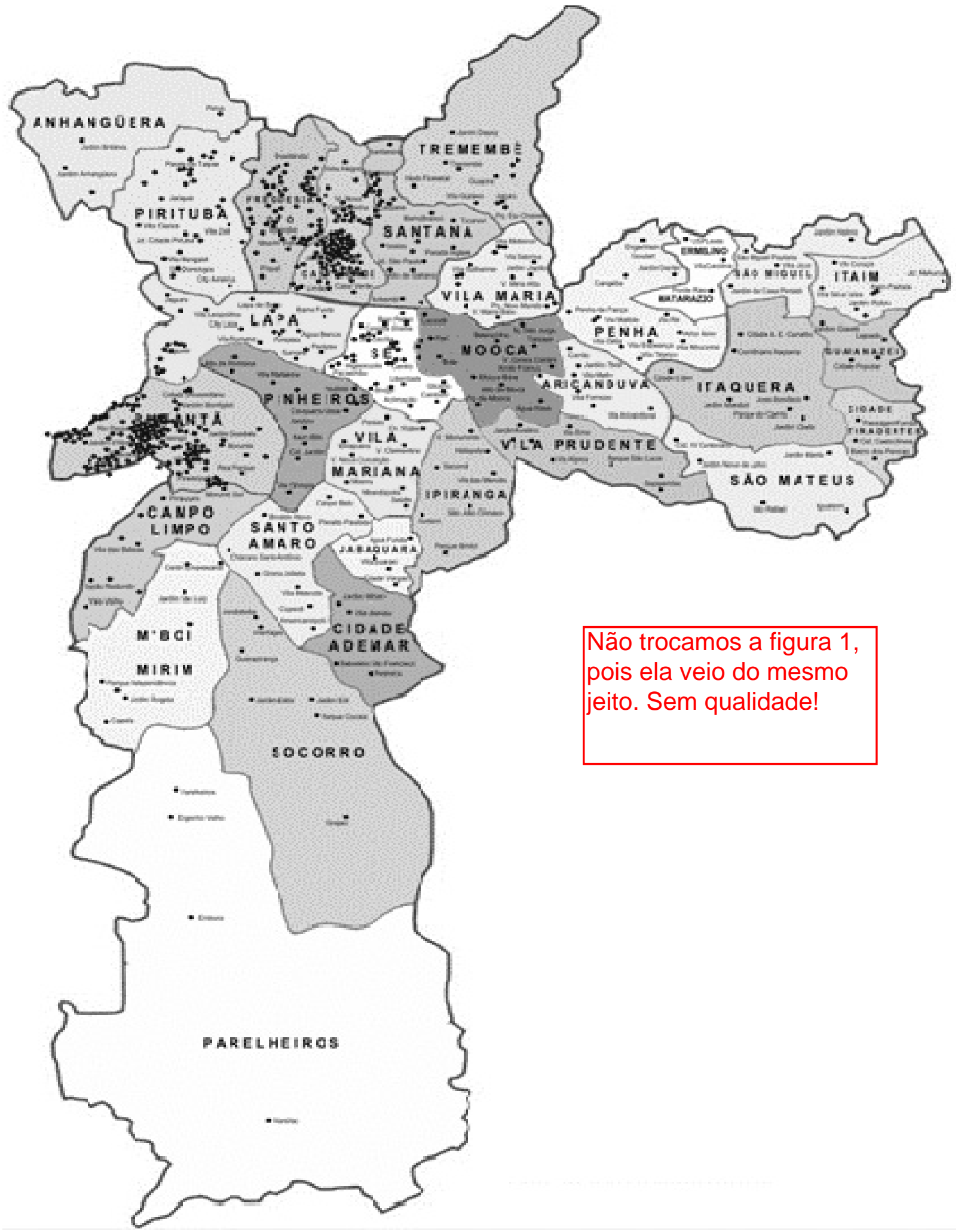

Figure 1 - Localization of the households (black spots) sampled in the São Paulo city. Source: adapted from pt.wikepedia.org 
sensation of these buildings. Similarly to outdoor environment, using the extremes of temperature and relative humidity variables. It was possible to simulate different internal scenarios, or four daily situations: maximum temperature and relative humidity maximum (hot and humid days: QU, situation 1); maximum temperature and relative humidity minimum (hot and dry days: QS, situation 2); minimum temperature and humidity maximum (cold and humid days: FU, situation 3); minimum temperature and humidity minimum (cold and dry days, FS: situation 4). The criteria used to classify the comfort threshold of the residences was the range from $22^{\circ} \mathrm{C}$ to $25^{\circ} \mathrm{C}$, suggested as "comfortable zone" (Fanger, 1972), which classifies the thermal comfort in five classes, ranging from very cold, until very hot. This zone is valid for a person with average clothing in sedentary activity, and weak winds.

\section{Discomfort Index (DI)}

Thom (1959) describe the searches conducted by Thom and Bosen about the problem of air-conditioned systems. These searches represented an important role in the understanding of the subject thermal comfort with the development of a Discomfort Index, DI (Thom, 1959). As several versions were created for this index, this study used the form suggested by Giles et al. (1990), already used by other researchers in Brazil (Maia, 2002; Braun, 2003), from the following equation:

$$
\mathrm{DI}=\mathrm{T}-0.55[(1-0.01 \mathrm{UR})(\mathrm{T}-14.5)]
$$

where:

$\mathrm{T}=$ air temperature $\left({ }^{\circ} \mathrm{C}\right)$;

$\mathrm{UR}=$ relative humidity (\%);

$\mathrm{DI}=$ Discomfort Index $\left({ }^{\circ} \mathrm{C}\right)$.

\section{Effective Temperature Index without wind (ET) and with wind $\left(\mathrm{ET}_{\mathrm{w}}\right)$}

The Effective Temperature Index (ET) was developed by Missenard (1937), who considers the meteorological parameters air temperature $\left({ }^{\circ} \mathrm{C}\right)$ and relative humidity $(\%)$ in its calculation. However, it is known that the thermal sensation perceived by people is often attributed also to the magnitude of wind and relative humidity. Several authors have related these variables to express this sensation in tropical climates environments. The relationship described by Missenard (1937) to designate Effective Temperature (ET) considers that

$$
E T=T-0.4[(1-U R / 100)(T-10)],
$$

where:

$\mathrm{T}=$ air temperature $\left({ }^{\circ} \mathrm{C}\right) ;$
$U R=$ relative humidity (\%);

$\mathrm{ET}=$ Effective Temperature $\left({ }^{\circ} \mathrm{C}\right)$.

Just as in Houghten \& Yaglou (1923), this calculation model overestimates the effect of relative humidity and does not consider a major effect in determining the effective temperature, which would be the average wind. However, Suping et al. (1992) appointed the effective temperature as being a function of the relative humidity and wind speed $\left(E T_{W}\right)$. The shape of the equation is:

$$
\begin{aligned}
E \mathrm{~T}_{\mathrm{W}}=37 & -\frac{(37-\mathrm{T})}{\left[(0.68-0.0014 \mathrm{UR})+1 /\left(1.76+1.4 \mathrm{~W}^{0.75}\right)\right]} \\
& -0.29 \mathrm{~T}(1-\mathrm{UR} / 100)
\end{aligned}
$$

where:

$\mathrm{T}=$ air temperature $\left({ }^{\circ} \mathrm{C}\right)$;

$U R=$ relative humidity (\%);

$\mathrm{W}=$ wind average speed $(\mathrm{m} / \mathrm{s})$, and

$\mathrm{ET}_{\mathrm{W}}\left({ }^{\circ} \mathrm{C}\right)$ is the Effective Temperature according to the wind.

Tables 1 and 2 show the thermal sensation and the thermal stress degree (levels of discomfort and physiological stress), for the $\mathrm{DI}, E \mathrm{ET}$ and $E \mathrm{~T}_{\mathrm{w}}$ indexes. Please note that the thermal zones (thresholds of temperatures for different thermal sensations) proposed in Table 1 are valid for wind speeds less than those used in the calculation of the index $E T_{w}$, therefore, that is not a perfectly applicable zone for this situation. In other words, the wind speeds considered by calculate to be smaller than they actually occur in the observations (IAG/USP station), however, it assists in the comparison with the other index.

\section{RESULTS AND DISCUSSION Outdoor Conditions}

The different comfort indexes were calculated for the three different situations (1, 2 and 3) for a period from 1980 to 2005 (9497 days). The climatological graphs of these indexes are presented below and show the comfortable regions (in gray), and uncomfortable regions by heat and by cold.

\section{Discomfort Index (DI)}

The Discomfort Index was created to observe comfort in airconditioned environments and was reported here for the outdoor environment. The results of this index are found for each situation in Figures 2, 3 and 4.

Figure 2 shows the climatological graph DI for the situation (1). In this situation, using average values for the variables, 
Table 1 - Levels of classification of the Discomfort Index, DI (Thom, 1959).

\begin{tabular}{|c|c|c|}
\hline $\mathrm{DI}\left({ }^{\circ} \mathrm{C}\right)$ & Level of discomfort & Thermal sensation \\
\hline$<21$ & None discomfort & Very cold \\
$21-24$ & Less than $50 \%$ has discomfort & Cold \\
$24-27$ & More than $50 \%$ has discomfort & Freeezing \\
$27-29$ & The most of population has discomfort & Comfortable \\
$29-32$ & Every has discomfort & Warm \\
$>32$ & Attention for medical emergency & Hot/Very Hot \\
\hline
\end{tabular}

Table 2 - Classification levels for ET W and ET (Fanger, 1972).

\begin{tabular}{|c|c|c|}
\hline$E T_{w}$ and $E T\left({ }^{\circ} \mathrm{C}\right)$ & Level of Phisiological stress & Thermal Sensation \\
\hline$<13$ & Extreme Stress by Cold & Very cold \\
$13-16$ & Shivering & Cold \\
$16-19$ & Lightly cold of the body & Slightly cold \\
$19-22$ & Vasoconstrition & Freezing \\
$22-25$ & Thermal neutrality & Comfortable \\
$25-28$ & Quick perspiration; vasodilatation & Warm \\
$28-31$ & Sweating & Slightly hot \\
$31-34$ & Intense sweat & Hot \\
$>34$ & Fails in thermo-regulation & Very Hot \\
\hline
\end{tabular}

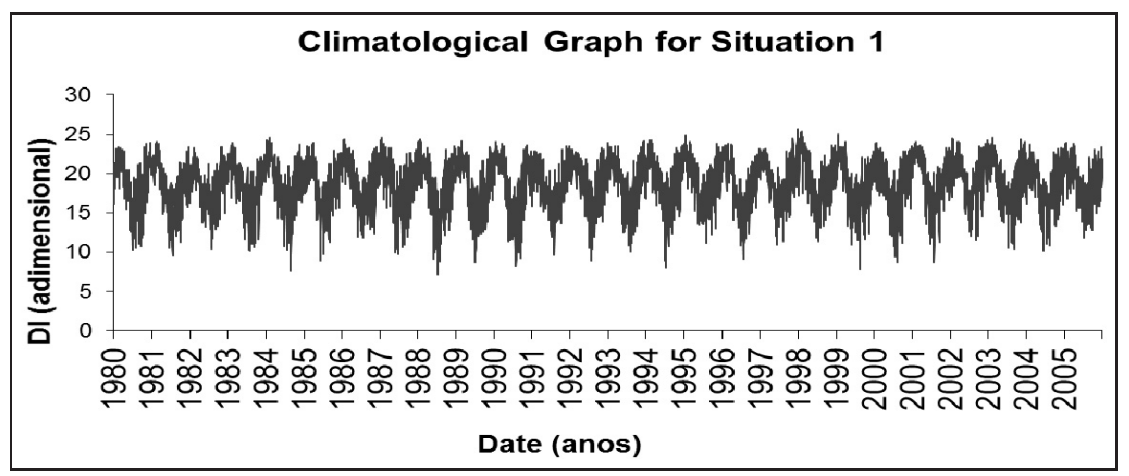

Figure 2 - Climatological Graph of the Discomfort Index for situation (1).

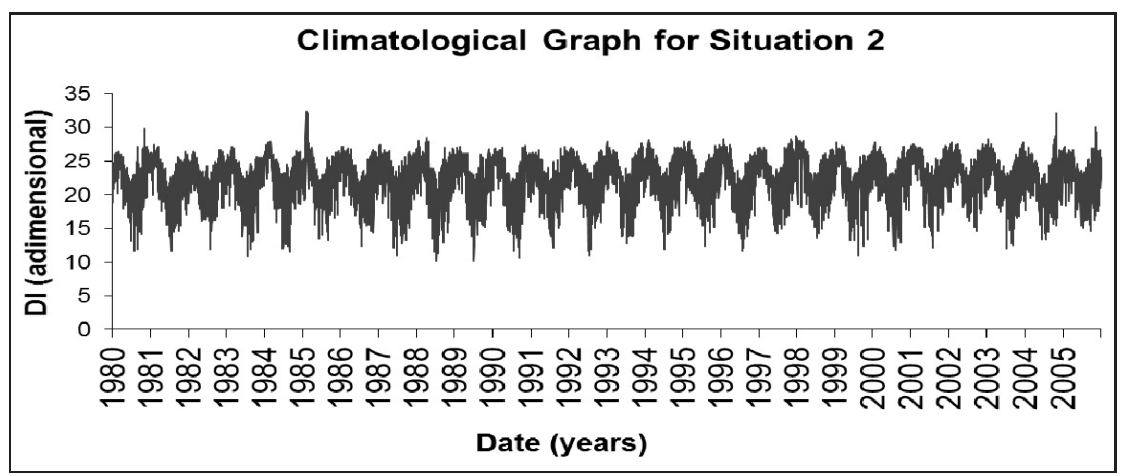

Figure 3 - Climatological Graph of the Discomfort Index for situation (2). 


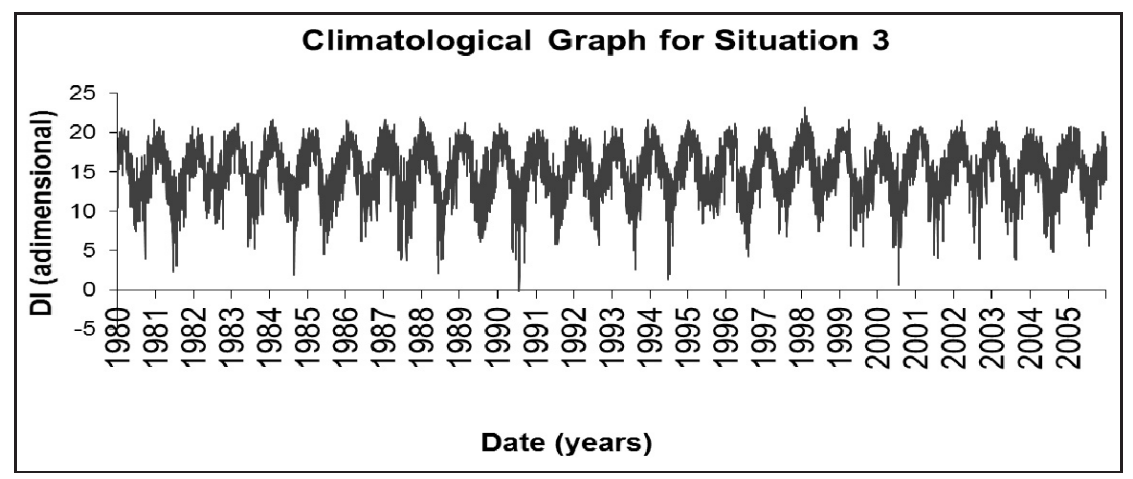

Figure 4 - Climatological Graph of the Discomfort Index for situation (3).

a greater concentration of values in the region of absence of discomfort $\left(\mathrm{DI}<21^{\circ} \mathrm{C}\right)$ was observed. It is interesting to note that the highest peaks values considered for discomfort of the MRSP was found in the months of January and February (the summer season) of 1998, but during the same months in previous years, some discomfort of the population was also observed.

Figure 3 shows the Discomfort Index for the situation (2), maximum temperature and relative humidity minimum (hot and dry days). There is a region with considerable lack of discomfort (comfortable), and some maximum values in regions where a large part of the population feels mild discomfort (DI $27-29^{\circ} \mathrm{C}$ ). Some episodes also occur where the entire population feels stress by heat ( $\mathrm{DI} 29-32^{\circ} \mathrm{C}$ ), caused by high temperatures observed during the afternoons of the months of February 1985 (average temperature $28.6^{\circ} \mathrm{C}$ ) and October $2004\left(23.6^{\circ} \mathrm{C}\right)$. Figure 4 shows the graph of the Discomfort Index for the situation (3) - minimum temperature and relative humidity maximum. It appears that almost the entire population feels no discomfort, except for some periods of summer, as the month of February 1998, whose cause was the high temperatures observed (discomfort by warm). Table 3 shows the absolute frequency and relative frequency for the classification of the Discomfort Index for each day of the year. With more detail it is possible to see in situations (1) and (3) that the number of days classified as "without discomfort" has significantly the highest values, $7010(73.81 \%)$ for the situation (1), and 9452 (99.53\%) for the situation (3). For the situation (2), beginning of the afternoon, 3507 (36.93\%) of the days were found in the classification "less than $50 \%$ of the population feels uncomfortable" and 3021 (31.81\%) of the days in the classification "more $50 \%$ of the population feels uncomfortable". This result showed a balance between these classifications (situation 2), probably by the major influence of temperature for this index. Thus, for the situation (1), $73.81 \%$ of days are comfortable and $26.19 \%$ are uncomfortable. This showed that according to the Discomfort Index (DI), the MRSP can be considered comfortable by the significant number of days in which this situation occurred.

\section{Effective Temperature according to the wind $\left(\mathrm{ET}_{\mathrm{w}}\right)$ and Effective Temperature (ET)}

The results of the evaluation of thermal sensation $\left(E T_{w}\right)$ in outdoor environment in the city of São Paulo are shown in Figures 5 , 6 and 7 . It was calculated the effective temperature, which takes into account the temperature and the relative humidity, and the effective temperature according to the wind that considers average wind besides the relative humidity and temperature. Average wind always tends to milden values in the region uncomfortable by heat, and enhance the values of the region presenting stress by cold.

Figure 5 provides the Climatological Graph of the Effective Temperature according to the wind for situation (1), average temperature and average humidity of the day can be felt taking into account beside relative humidity, the wind speed. It was observed that most of the days were uncomfortable by cold, with some rapid peaks in the region of comfort ( $E T_{w}$ between $22-25^{\circ} \mathrm{C}$ ). It is noticeable a lot of day observed in the "very cold" region (with $\mathrm{ET}_{\mathrm{w}}$ $<13^{\circ} \mathrm{C}$ ). These values of effective temperature according to wind were low, possibly by significant average wind speed of these 25 years of studies $(1.74 \mathrm{~m} / \mathrm{s})$. Again, the climatology for this index shows the highest peaks in February 1998 and the lowest value in the month of July $1988\left(-2.2^{\circ} \mathrm{C}\right)$. Figure 6 shows the climatological graph of $\mathrm{ET}_{\mathrm{w}}$ for situation (2), maximum temperature and humidity minimum. There is a considerable concentration of values in the "comfortable" region ( $E \mathrm{~T}_{\mathrm{w}}$ between $22-25^{\circ} \mathrm{C}$ ), as well as, a big amount of values in the region of discomfort by cold. It is worth noting also the emergence of a small uncomfortable range relating to heat, "slightly warm" ( $E T_{w}$ between $25-28^{\circ} \mathrm{C}$ ) and of 
Table 3 - Levels of classification of the Discomfort Index of the studied climatology (1980-2005).

\begin{tabular}{|c|c|c|c|c|c|c|}
\hline \multirow{2}{*}{ Classification } & \multicolumn{2}{|c|}{ Situation (1) } & \multicolumn{2}{c|}{ Situation (2) } & \multicolumn{2}{c|}{ Situation (3) } \\
\cline { 2 - 7 } & Days & $\%$ & Days & $\%$ & Days & $\%$ \\
\hline Without discomfort & 7010 & 73.81 & 2738 & 28.83 & 9452 & 99.53 \\
Less than 50\% has discomfort & 2421 & 25.59 & 3507 & 36.93 & 45 & 0.47 \\
More than 50\% has discomfort & 66 & 0.69 & 3021 & 31.81 & 0 & 0.00 \\
The most of population has discomfort & 0 & 0.00 & 214 & 2.25 & 0 & 0.00 \\
Every has stress & 0 & 0.00 & 14 & 0.15 & 0 & 0.00 \\
Attention for medical emergency & 0 & 0.00 & 0 & 0.00 & 0 & 0.00 \\
Total Comfortable & 7010 & 73.81 & 2738 & 28.83 & 9452 & 99.53 \\
Total Discomfortable & 2487 & 26.19 & 6756 & 71.14 & 45 & 0.47 \\
\hline
\end{tabular}

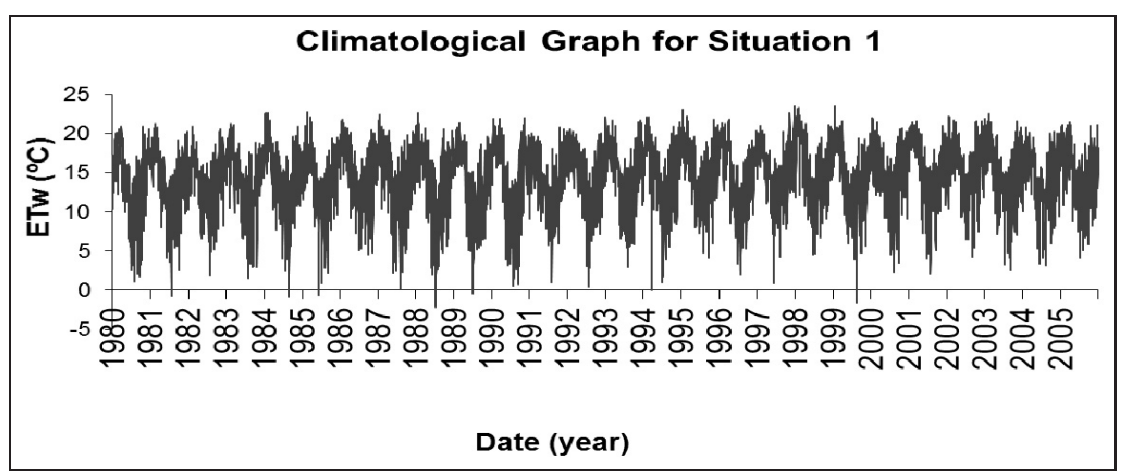

Figure 5 - Climatological Graph of the Effective Temperature according to the wind for situation (1).

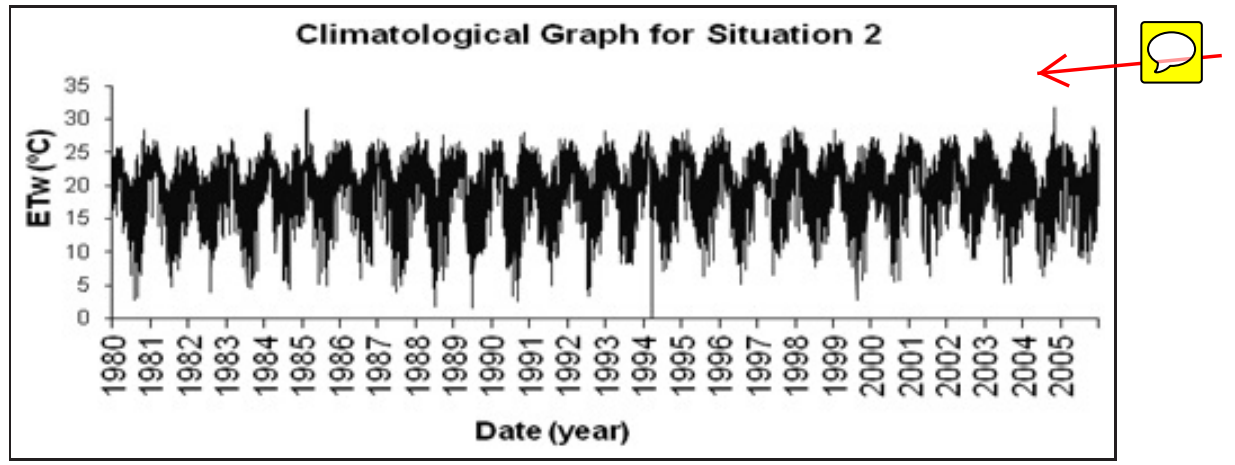

Figure 6 - Climatological Graph of the Effective Temperature according to the wind for situation (2).

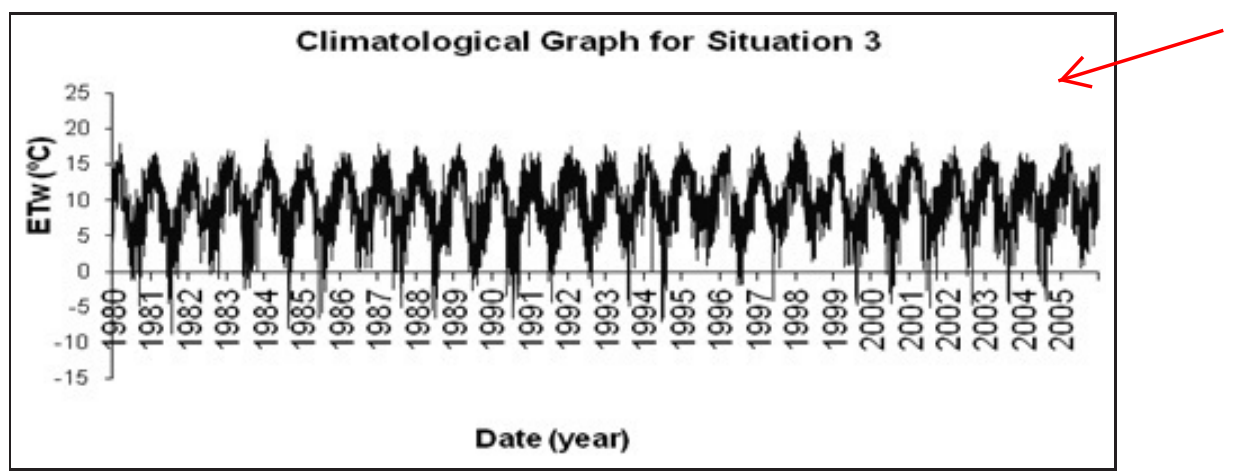

Figure 7 - Climatological Graph of the Effective Temperature according to the wind for situation (3). 
two periods considered uncomfortable by heat $\left(\mathrm{ET}_{\mathrm{w}}\right.$ between 31$34^{\circ} \mathrm{C}$ ). Figure 7 shows the $E T_{w}$ graph for the situation (3), minimum temperature and humidity maximum. There are rather uncomfortable regions throughout the period, even presenting extreme stress in relation to cold $\left(E \mathrm{~T}_{\mathrm{W}}<13^{\circ} \mathrm{C}\right)$. Table 4 offered absolute frequency and relative frequency of the Effective Temperature Index according to the wind $\left(\mathrm{ET}_{\mathrm{w}}\right)$ for all the studied period. The classification "very cold" was felt most of the days (3211 or 33.81\%), in situation (1) and in situation (3), (6941 or $73.09 \%$ ). But in situation (2), the number of days classified as "slightly cold" was the biggest for 2586 days (27.23\%), approaching the comfortable sensation (2336 or $24.60 \%$ ). This probably occurred by the action of wind, which reduced the discomfort, (maximum temperature and humidity minimum). Thus, situation (1) marked up in virtually all the days as uncomfortable by cold (99.57\%). For situation (2), $64 \%$ of the days had the same classification and in situation (3), the whole period was considered uncomfortable by cold. The discomfort by heat was expressed only in situations (1) and (2), for $0.43 \%$ and $11 \%$ of the days, respectively.

Figures 8,9 and 10 show the graphs for the same studied situations, but now for the Effective Temperature (ET), without the action of the wind. It was observed for all situations similar pattern graphs of the effective temperature according to the wind $\left(\mathrm{ET}_{\mathrm{w}}\right)$. However, there was a shift of ET for the regions of higher temperatures (stress by hot), confirming that the wind speed is a variable of fundamental importance to quantify and qualify their effect on the sensation of comfort perceived by the human body. Table 5 presents the absolute frequency and relative frequency for the classification of the Effective Temperature Index (ET) of the studied period. For situation (1), the feeling of "slightly cold" predominated in most days (3328, or 35.04\%). In the situation (2), the discomfort by "moderate cold" prevailed (3029, or $31.89 \%)$ and for situation (3) - minimum temperature and humidity maximum - the classification comfortable was present in 3312 days (34.87\%). It was observed that for the three situations the feeling of discomfort by cold prevailed in most of the days studied. The feeling of comfort for the population of São Paulo was present in situations (2) and (3) $-\mathrm{T}_{\max }$ and $\mathrm{RH}_{\min }$ and $\mathrm{T}_{\min }$ and $\mathrm{RH}_{\max }$, respectively. Only situation (2), presented physiological stress caused by heat, that is, a short period (25\%) over the 25 years studied was representative to the discomfort by heat.

Table 6 shows the behavior of average values for each index of comfort ( $E T$ and $E T_{w}$ ) according to the seasons. Since an average of the indexes for each month was made, the result found did not include the extreme values, giving an approximate clas- sification of each season of the year. It is understood WD, Without Discomfort; SD, Some Discomfort; MC, Moderate Cold; VC, Very Cold; C, Cold; SC, Slightly Cold; -50 P, less than $50 \%$ of the population feels discomfort; $+50 \mathrm{P}$, more than $50 \%$ of the population feels discomfort; TC, Thermal Comfort. The hypothetical situations (1), (2) and (3), are represented by the indexes $\mathrm{DI}, \mathrm{ET}_{\mathrm{w}}, \mathrm{ET}$, with their respective sub-indexes. Considering the $\mathrm{Dl}_{1}$ for situation (1) $\left(\mathrm{T}_{\text {avg }}, \mathrm{RH}_{\text {avg }}\right)$ it is observed that only during the summer the index presented discomfort in relation to the heat. The $\mathrm{ET}_{\mathrm{W} 1}$ always presented itself as uncomfortable by cold (MC, C, VC, C), showing an average of summer and winter months with extremes of "moderate cold"; and "very cold", respectively. Similar characteristics were shown by $\mathrm{ET}_{1}$ index, moving sensations to less cold regions (SC, C), due to the absence of wind speed in calculation. For situation (2) $\left(\mathrm{T}_{\max }, \mathrm{RH}_{\min }\right)$ the $\mathrm{DI}_{2}$ showed slight discomfort over the year, however, during the winter such discomfort was not evident, suggesting that in the afternoons (maximum temperatures) the high temperatures milden the cold for this time of year. Observing the $\mathrm{ET}_{\mathrm{W} 2}$ and $\mathrm{ET}_{2}$, it is noted that the summer afternoons were comfortable, and in the winter, they ranged from moderately cold to slightly cold (MC, SC). For situation (3) $\left(\mathrm{T}_{\min }\right.$ and $\left.\mathrm{RH}_{\max }\right)$ the $\mathrm{Dl}_{3}$ was found, with absence of discomfort in all seasons. For the $\mathrm{ET}_{\mathrm{W}_{3}}$ and $\mathrm{ET}_{3}$ indexes, great discomfort by cold was presented in all seasons throughout the year. The city of São Paulo during the winter, has presented very cold mornings (VC), and during summer range from cold to moderately cold mornings $(C, M C)$. It is noteworthy that for all the presented situations, the absence of wind in the ET index tends to reduce the discomfort by cold during the mornings, $\left(T_{\min }\right.$ and $\left.\mathrm{RH}_{\max }\right)$ in the winter and increase the discomfort by heat during the summer afternoons $\left(T_{\max }\right.$ and $\left.\mathrm{RH}_{\min }\right)$, when compared to the $\mathrm{ET}_{\mathrm{w}}$ average index for the same periods.

Both biometeorological indexes $E T$ and $\mathrm{ET}_{\mathrm{w}}$ may be representative of the climate conditions (outdoor) experienced in the metropolitan region of São Paulo (MRSP). According to the classification, the ET index is consistent in pointing out strong thermal stress by cold during the mornings $\left(\mathrm{ET}_{1}\right)$ in the winter, and comfort conditions during summer $\left(\mathrm{ET}_{2}\right)$. The presence of wind in the $\mathrm{ET}_{\mathrm{w}}$ index moves the thermal sensation to intervals of lower temperature, increasing the cold sensation observed during winter and making summer afternoons comfortable $\left(E T_{W_{2}}\right)$. During the rest of the year, the indexes showed that there is discomfort in relation to cold and, as well as for the summer and winter, the action of the wind $\left(E T_{W}\right)$ tends to increase this condition of discomfort. The representation of these indexes leads to conclusion that São Paulo city suffers more from cold 
Table 4 - Levels of classification of the Effective Temperature according to the wind (ETw) of the studied climatology (1980-2005).

\begin{tabular}{|c|c|c|c|c|c|c|}
\hline \multirow{2}{*}{ Classification } & \multicolumn{2}{|c|}{ Situation (1) } & \multicolumn{2}{c|}{ Situation (2) } & \multicolumn{2}{c|}{ Situation (3) } \\
\cline { 2 - 7 } & Days & $\%$ & Days & $\%$ & Days & $\%$ \\
\hline Very cold & 3211 & 33.81 & 811 & 8.53 & 6941 & 73.09 \\
Cold & 2505 & 26.38 & 983 & 10.35 & 2181 & 22.97 \\
Slightly & 2600 & 27.38 & 1696 & 17.86 & 372 & 3.92 \\
Freezing & 1140 & 12.00 & 2586 & 27.23 & 3 & 0.03 \\
Comfortable & 41 & 0.43 & 2336 & 24.60 & 0 & 0.00 \\
Warm & 0 & 0.00 & 1048 & 11.04 & 0 & 0.00 \\
Slightly hot & 0 & 0.00 & 34 & 0.36 & 0 & 0.00 \\
Hot & 0 & 0.00 & 3 & 0.03 & 0 & 0.00 \\
Very hot & 0 & 0.00 & 0 & 0.00 & 0 & 0.00 \\
Discomfortable by cold & 9456 & 99.57 & 6076 & 63.97 & 9497 & 100.00 \\
Comfortable & 41 & 0.43 & 2336 & 24.60 & 0 & 0.00 \\
Discomfortable by hot & 0 & 0.00 & 1085 & 11.43 & 0 & 0.00 \\
\hline
\end{tabular}

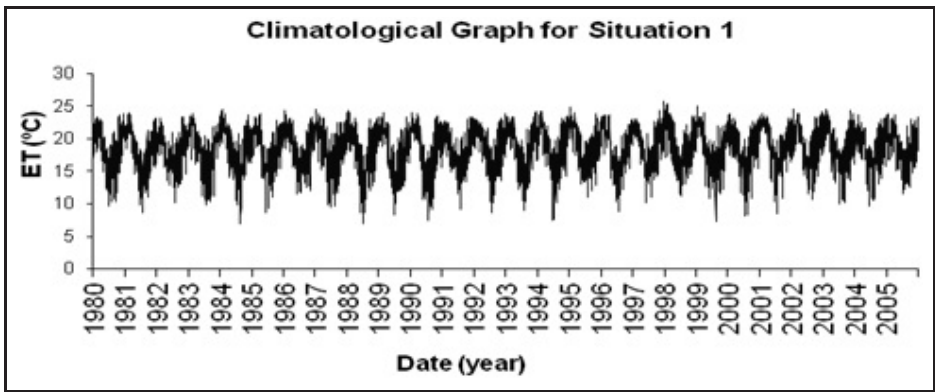

Figure 8 - Climatological Graph for Effective Temperature for situation (1).

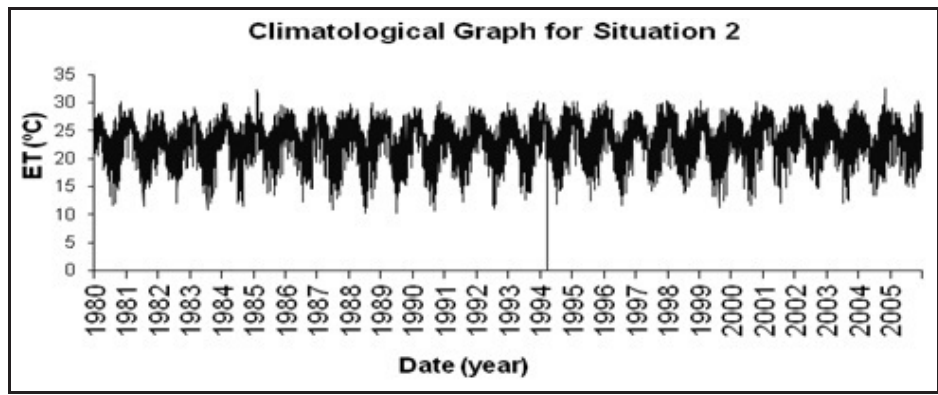

Figure 9 - Climatological Graph for Effective Temperature for situation (2).

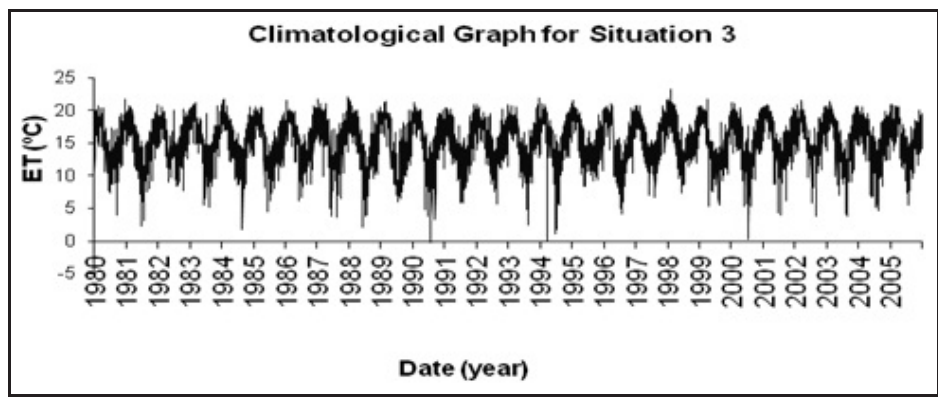

Figure 10 - Climatological Graph for Effective Temperature for situation (3). 
Table 5 - Classification of the ET index of the studied climatology (1980-2005) separated by comfortable and uncomfortable days in the cold and hot region.

\begin{tabular}{|c|c|c|c|c|c|c|}
\hline \multirow{2}{*}{ Classification } & \multicolumn{2}{|c|}{ Situation (1) } & \multicolumn{2}{c|}{ Situation (2) } & \multicolumn{2}{c|}{ Situation (3) } \\
\cline { 2 - 7 } & Days & $\%$ & Days & $\%$ & Days & $\%$ \\
\hline Very cold & 498 & 5.24 & 65 & 0.68 & 2595 & 27.32 \\
Cold & 1509 & 15.89 & 379 & 3.99 & 2792 & 29.40 \\
Slightly & 2966 & 31.23 & 1111 & 11.70 & 3029 & 31.90 \\
Feezing & 3328 & 35.04 & 2328 & 24.51 & 1078 & 11.35 \\
Comfortable & 1190 & 12.53 & 3312 & 34.87 & 3 & 0.03 \\
Warm & 6 & 0.06 & 2199 & 23.15 & 0 & 0.00 \\
Slightly hot & 0 & 0.00 & 96 & 1.01 & 0 & 0.00 \\
Hot & 0 & 0.00 & 7 & 0.07 & 0 & 0.00 \\
Very hot & 0 & 0.00 & 0 & 0.00 & 0 & 0.00 \\
Discomfortable by cold & 8301 & 87.40 & 3883 & 40.88 & 9494 & 99.97 \\
Comfortable & 1190 & 12.53 & 3312 & 34.87 & 3 & 0.03 \\
Discomfortable by hot & 6 & 0.06 & 2302 & 24.23 & 0 & 0.00 \\
\hline
\end{tabular}

Table 6 - Classification of the average comfort indexes (ET and $E T_{W}$ ), according to the seasons of the years (1980-2005). Where: WD, Without Discomfort; SD, Some Discomfort; MC, Moderate Cold; VC, Very Cold; C, Cold, SC, Slightly Cold; $-50 P$, less than $50 \%$ of the population feels discomfort; $+50 \mathrm{P}$, more than $50 \%$ of the population feels discomfort; TC, Thermal Comfort sensation.

\begin{tabular}{|c|c|c|c|c|c|c|c|c|c|}
\hline Season & $\mathrm{Dl}_{1}$ & $\mathrm{Dl}_{2}$ & $\mathrm{Dl}_{3}$ & $\mathrm{ET}_{\mathrm{W} 1}$ & $\mathrm{ET}_{\mathrm{W}}$ & $\mathrm{ET}_{\mathrm{W}}$ & $\mathrm{ET}_{1}$ & $\mathrm{ET}_{2}$ & $\mathrm{ET}_{3}$ \\
\hline Summer & $-50 \mathrm{P}$ & $+50 \mathrm{P}$ & $\mathrm{WD}$ & $\mathrm{MC}$ & $\mathrm{TC}$ & $\mathrm{C}$ & $\mathrm{SC}$ & $\mathrm{TC}$ & $\mathrm{MC}$ \\
Autumn & $\mathrm{WD}$ & $-50 \mathrm{P}$ & $\mathrm{WD}$ & $\mathrm{C}$ & $\mathrm{SC}$ & $\mathrm{VC}$ & $\mathrm{MC}$ & $\mathrm{SC}$ & $\mathrm{C}$ \\
Winter & $\mathrm{WD}$ & $\mathrm{WD}$ & $\mathrm{WD}$ & $\mathrm{VC}$ & $\mathrm{MC}$ & $\mathrm{VC}$ & $\mathrm{C}$ & $\mathrm{SC}$ & $\mathrm{VC}$ \\
Spring & $\mathrm{WD}$ & $-50 \mathrm{P}$ & $\mathrm{WD}$ & $\mathrm{C}$ & $\mathrm{SC}$ & $\mathrm{VC}$ & $\mathrm{SC}$ & $\mathrm{TC}$ & $\mathrm{C}$ \\
\hline
\end{tabular}

than hot days. However, such conclusion could be influenced by comfort zone unfit for the region, and that zone, should perhaps be below the standard set for local population, in other words, the thermal comfort sensation might be felt at range of temperatures smaller than here considered. A proper comfort zone for the region could be determined by a study where in addition to the measurements of all the variables involved between body and environment, were applied a questionnaire about the thermal sensations of the population (Givoni, 1999; Givoni \& Vecchia, 2001; Paps \& Lamberts, 2001; Maia, 2002; Braun, 2003; Monteiro \& Alucci, 2005).

\section{Indoor Conditions}

The Figure 11 to Figure 14 present the behavior of the Effective Temperature Index (ET), for each climate season of the year 2005. The graphs for four different daily situations (QU, QS, FU and FS): maximum temperature and maximum relative humidity (QU, situation 1); maximum temperature and minimum relative humidity (QS, situation 2); minimum temperature and maximum humidity (QU, situation 3); minimum temperature and minimum humidity
(FS, situation 4). Will be shown, within each season, the eight dwelling that had more valid measures (date without errors) and had similar periods of measures with other residences (in order to compare, in pairs, different kinds of residences - your constructive types and geographic localization). For each climatic season, there is a comparative graph of the external environmental conditions ( $\mathrm{T}$ and $\mathrm{RH}$ ).

\section{Autumn}

Figure 11 (graphs 1 to 8) shows the distribution of the "indoor" Effective Temperature Index (ET) for eight from 272 sampled residences during the season of autumn of 2005, in the city of São Paulo. In the same Figure 11 (graphs 9 and 10), it is given the behavior of outdoor temperature and relative humidity (IAG station) and their respective ET index (outdoor), calculated for the autumn season. The houses were grouped two by two, purposely to examine how they would respond to external synoptic conditions, if these measures were held in the same period of time and under the same external influences. This season is characterized in general, as comfortable for $75 \%$ of the examined residences 


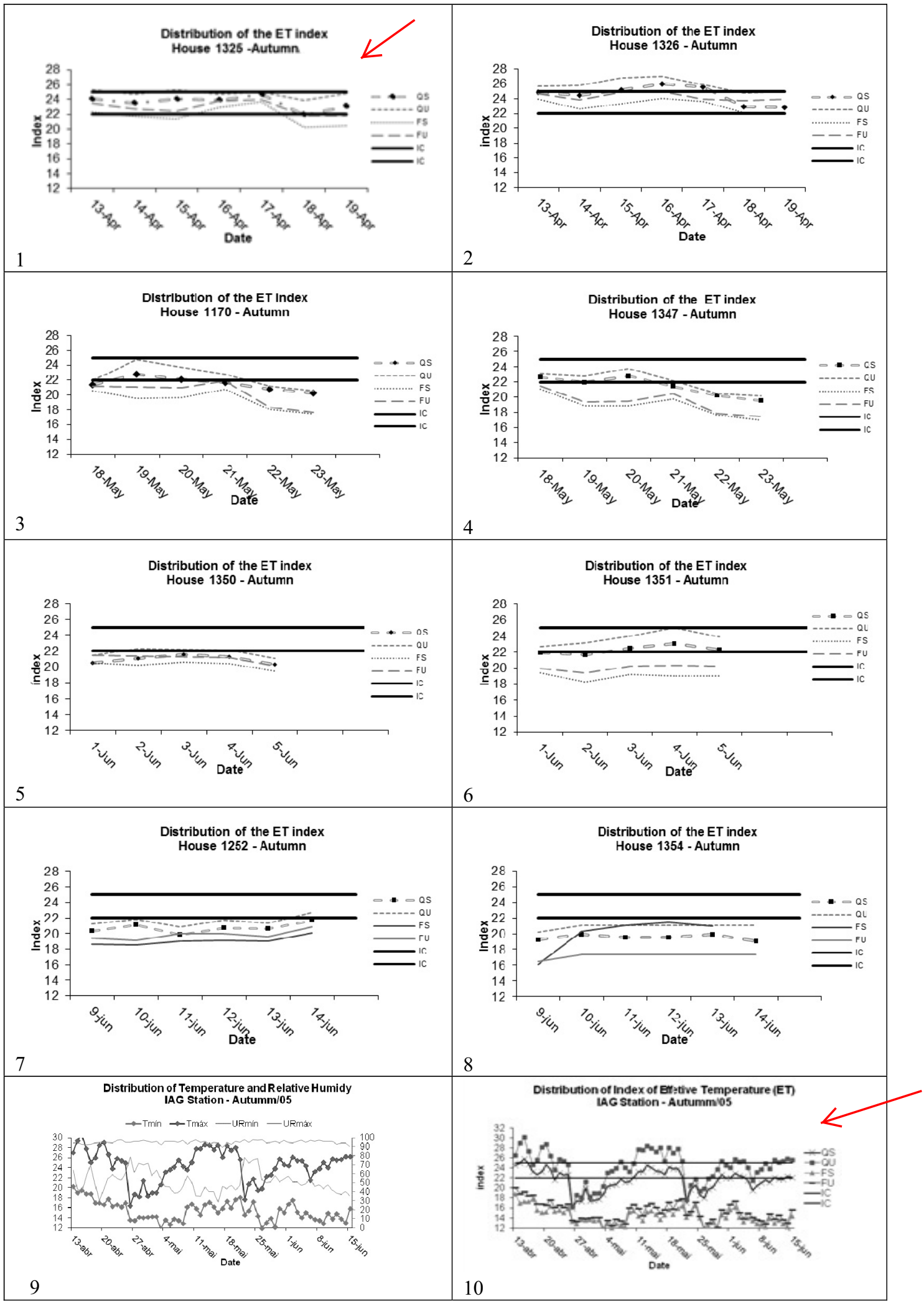

Figure 11 - Distribution of the ET indexes, for the autumn of 2005. 
(6 houses), however, during the mornings there is a mild discomfort in relation to cold at all of them. The afternoons were characterized, according to the ET index, as comfortable and with very mild temperatures, ranging between 21 and $27^{\circ} \mathrm{C}$. It is interesting to note that, as the winter approaches, the internal discomfort in relation to cold during the morning tends to increase (houses $1351,1352,1354)$, getting to persist for six days with temperatures around 17 degrees (FS/FU), (house 1354). This discomfort can be better illustrated if we observe the behavior of external minimum temperatures (graph 9), which tend to decrease, because, climatologically, the winter presents much lower temperatures than the autumn. Perhaps that is the explanation for that greater discomfort previously found. Through this preliminary analysis, it appears that residences respond in a way very similar to each other, especially when referring to external conditions. An example can be presented with houses 1170 and 1347, where a maximum heating was observed externally on May 18. House 1350 responded to this warming on the same day 18, but house 1170 , only on the 19th. There is a lag, for heating, of one day. Regarding an episode of cold occurred on May 21, the same houses (1170 and 1347) responded in similar way to external conditions, and faster than in the previously cited heating episode. Both houses identified such discomfort by cold (FS/FU, $18^{\circ} \mathrm{C}$ ) on the same day (May 21).

So, regarding the delay in heating, previously cited, how can we evaluate it? Questions like this can be answered through a deeper analysis, based on the application of different statistical methods to data and, with a better characterization of the residences. That is, it is necessary to evaluate, for example, the characteristics and level of occupancy of their environments, to get a better understanding of this issue.

\section{Winter}

Figure 12 (graphs 1 to 8) presents the behavior of the different situations of time experienced with the ET index, and the behavior of eight, from 60 residences sampled during the winter of 2005. Still through the picture (graphs 9 and 10), it illustrates the behavior of temperature and relative humidity outside the houses and the respective ET index. It may be noted that during the winter in the vast majority of the houses $(90 \%)$, there is the situation of thermal discomfort (stress) due to cold and this happens mainly during the morning (FS). The exception is the house 1174, which presents practically during the whole period measured (seven days), temperatures near and within the zone of comfort in the mornings, and comfortable temperatures during the afternoons (QS/QU), which may be due to the beginning of the spring (22/9), when temperatures tend to be more mild. This is confirmed in the graphs 9 and 10, where it is observed a rise with the approach of spring, both in external temperatures as in the external ET index. The cooler days and therefore, of the greatest stress due to cold, were in the period between June 22 and June 27, when the lowest value for $\mathrm{ET}$ was calculated: $15^{\circ} \mathrm{C}$ for the morning of the 22nd (houses 1359 and 1360). Externally, the minimum temperature reached its lowest value on July $26: 5.2^{\circ} \mathrm{C}$. Another factor that may be highlighted is that each residence responds differently during the season of winter. For example: residences measured in the same period have different thermal sensations. Periods which are considered as comfortable for a particular location (house 1174), can be classified as extremely unpleasant for others (house 1168). This suggests that there are differences between the residences, either in relation to protection against the cold, or in relation to lack of ventilation with the external environment, taking into account that they are all exposed to the same external synoptic conditions.

Comparing with the Figure 11, this thermal performance does not happen to the residence during the season of autumn, a fact that leads us to believe that during winter the exchanges of heat with the external environment are less frequent. Just as for the autumn, a further analysis is necessary, where we must take into account several factors, more specific to each residence, like the characteristics of housing (coverage; ceiling; orientation of windows and walls in relation to the sun; Structure of the building), changes in external weather conditions and use of it by its occupants.

\section{Spring}

Figure 13 (graphs 1 to 8 ) shows the distribution of the indoor Effective Temperature Index (ET) for eight, from 479 days studied during the spring 2005. Graphs 9 and 10, in the same figure, present the behavior of outdoor temperature and relative humidity (IAG station), and its respective ET index. It is possible to see that the mornings had been uncomfortable and stressful due to the cold (FS) in virtually all residences $(90 \%)$ except house 1266 which presented comfortable mornings for four, of the six days examined. This discomfort in relation to cold was higher in the second half of September, which presented externally very low temperatures for the period, especially in its last week, when the minimum temperature reached $11^{\circ} \mathrm{C}$ and the maximum temperature has not passed the $14^{\circ} \mathrm{C}$ (graph 9). However, with the approach of the summer season (graphs 7 and 8), the mornings become more pleasant and the days tend to be more comfortable. In the spring afternoons, there was almost no stress related to 


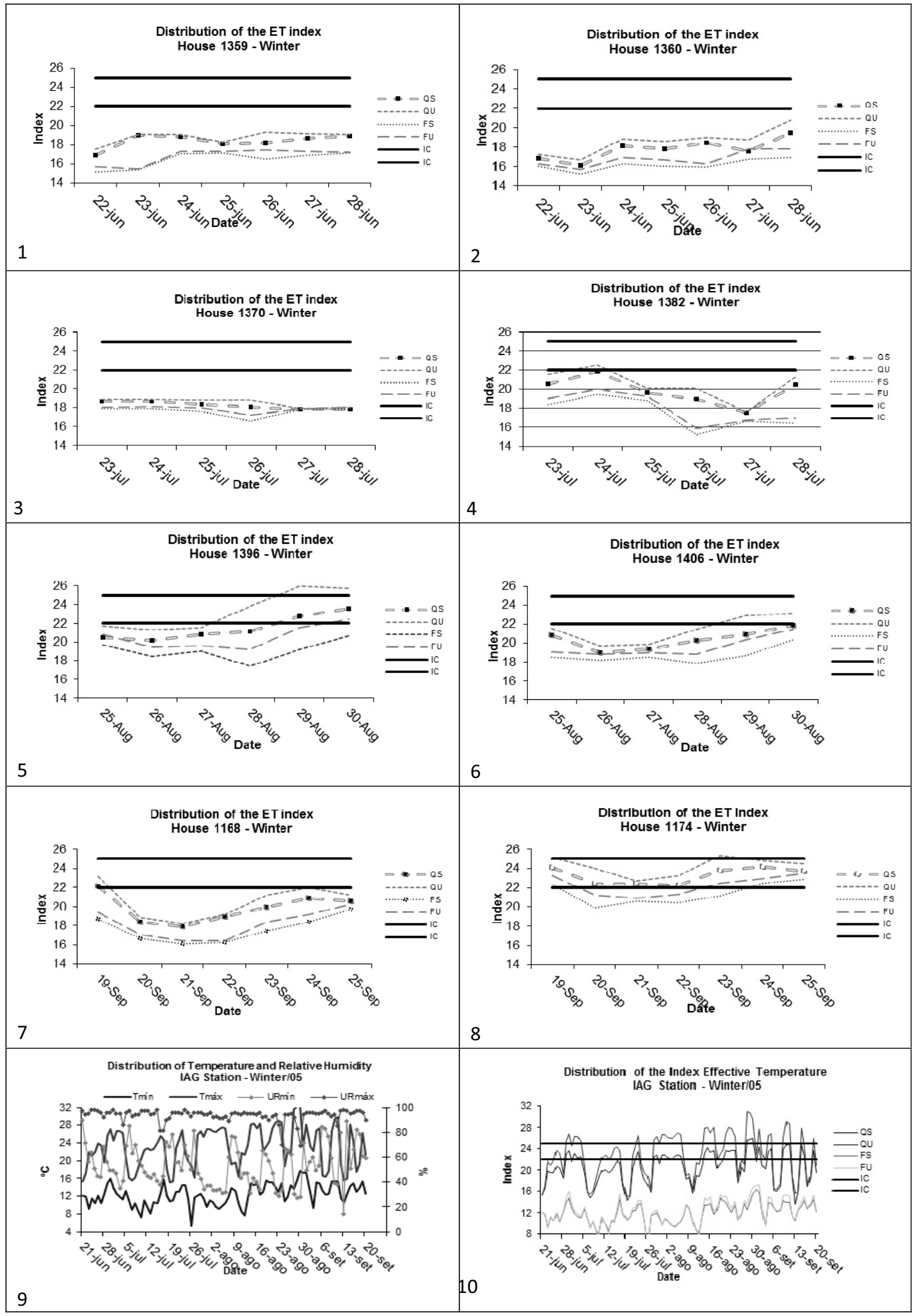

Figure 12 - Distribution of the ET indexes, for the winter of 2005. 


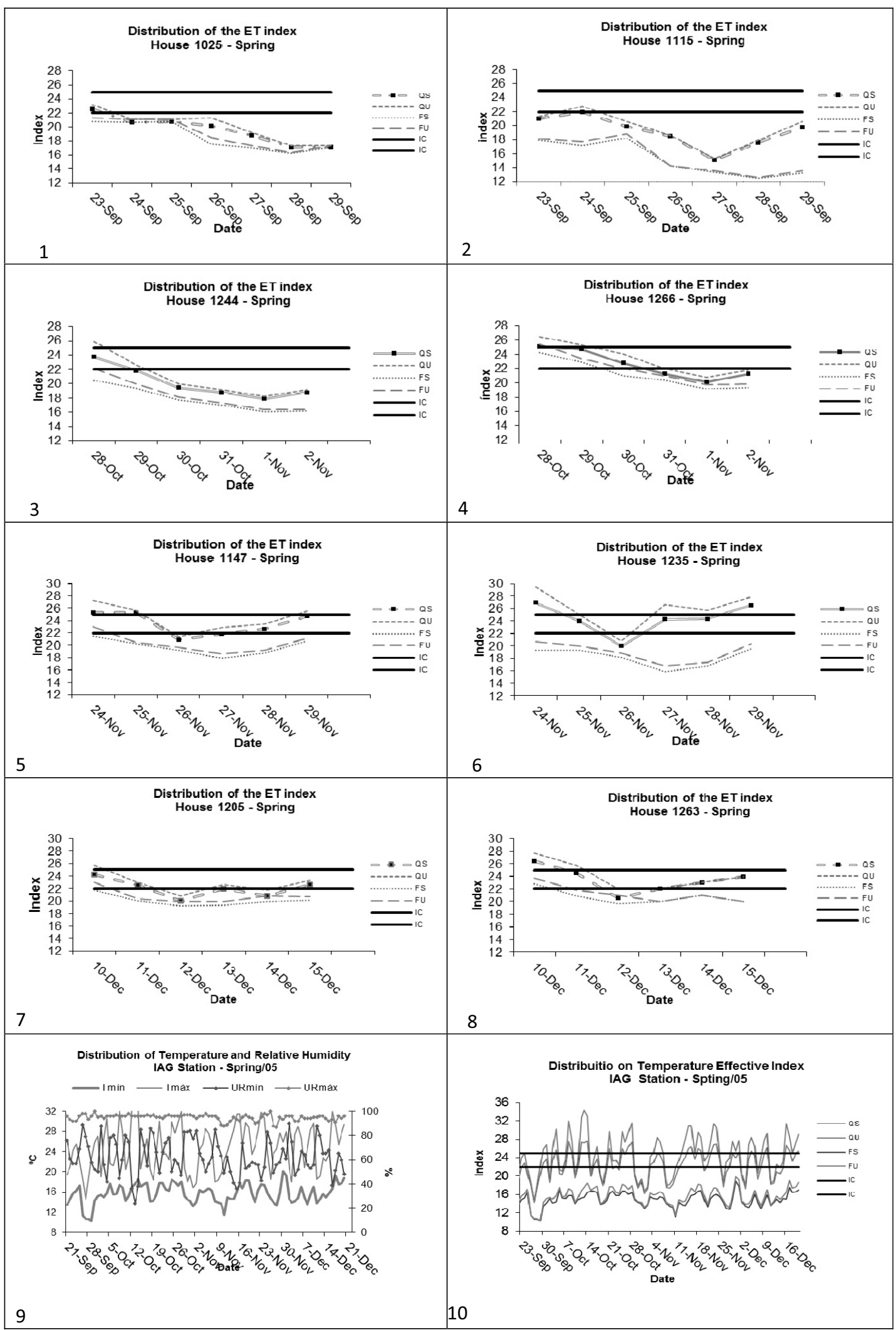

Figure 13 - Distribution of the ET indexes, for the spring of 2005. 


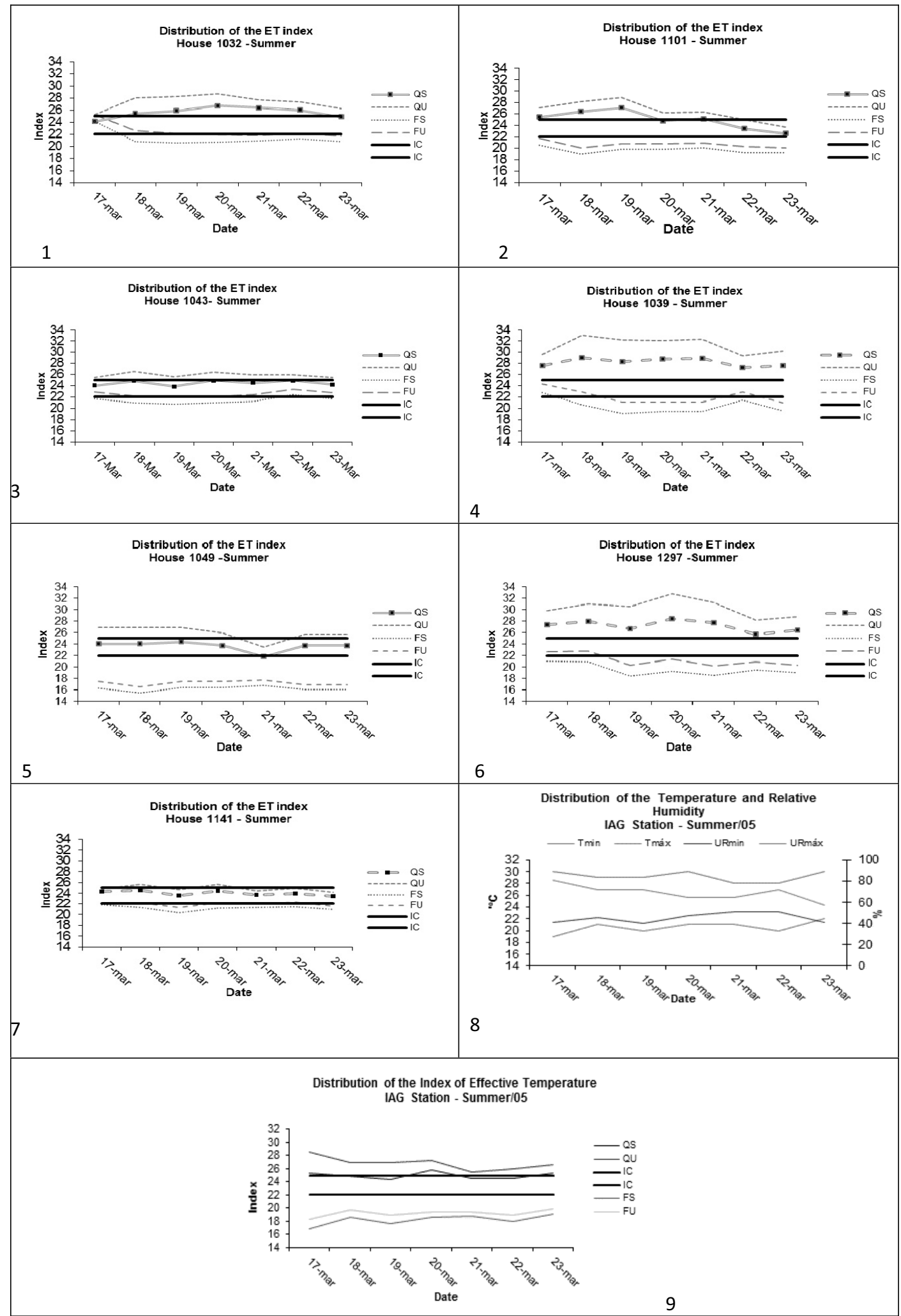

Figure 14 - Distribution of the ET indexes, for the summer of 2005. 
heat. Rather, it was observed that the afternoons had been comfortable and pleasant, with mild temperatures for half $(50 \%)$ of the examined residences, also in the months of November and December when the temperatures begin to increase because of the approach of summer.

Observing the external behavior of temperature (graph 9), we note that the spring of 2005 was characterized by very low temperatures, throughout the entire season, even surpassing the extremes of cold in winter, with the mark of $10.7^{\circ} \mathrm{C}$.

\section{Summer}

Figure 14 (graphs 1 to 7) presents the distribution of the indoor Effective Temperature Index (ET) for 7 residences studied (due to the finish of the project, only 7 dwellings were measures). Graphs 8 and 9, in the same figure, show the behavior of outdoor temperature and relative humidity (IAG station), and their respective ET index. It is worth emphasizing that the period in which the measures were taken is the end of the summer (March 2005) and as such, the preliminary comfort analysis in this station could provide only a partial idea of thermal comfort/discomfort of residences, not being representative for the three months that comprise the season of summer. It is possible to observe that the majority of the residences $(60 \%)$ showed heatrelated-discomfort during the afternoons, with the combination of high temperatures and high humidity (QS/QU). The greatest stress with the ET index was reached on March 17, reaching the mark of $33^{\circ} \mathrm{C}$, however, that discomfort was representative for four (houses 1032, 1101, 1039, 1297), from the seven analyzed residences. Moreover two houses $(1043,1141)$ were comfortable during practically all analyzed days. The mornings for this season, in general, were characterized as comfortable, although it altered slight feelings of discomfort by cold. The exception was the house 1049 (graph 5), which remained very uncomfortable due to cold for the seven measured days, even presenting values of the order of $15^{\circ} \mathrm{C}$, during the morning of day eighteen. This residence has a poor (underprivileged) localization in the city and receives little sunlight (in a slum, with one house on the other).

As for the external conditions (graph 9, IAG station) for the summer season, there were mornings that alternated periods of mild discomfort until very uncomfortable in relation to cold $\left(16.5^{\circ} \mathrm{C}\right.$, on March 17$)$. The afternoons showed temperatures close to the comfort zone, except for day 17, when a slight discomfort in relation to the heat was recorded $\left(28^{\circ} \mathrm{C}\right)$.

\section{CONCLUSIONS}

The biometeorological indexes $E T$ and $E T_{w}$ analyzed in this study are similar and corroborate (agree) previous studies (Maia, 2002; Braun, 2003) that also show that these (indexes) may be representative of the climate conditions (thermal sensations) experienced in the metropolitan region of São Paulo (MRSP). The ET 1 index is consistent in pointing out strong thermal stress by cold during the mornings in the winter, and comfort conditions during summer $\left(E T_{2}\right)$. The presence of wind in the $E T_{w}$ index moves the thermal sensation to intervals of lower temperature, increasing the cold sensation during winter, however, making summer afternoons more comfortable $\left(E T_{W_{2}}\right)$. During the rest of the year, the indexes showed that there is discomfort in relation to cold and the action of the wind $\left(E T_{w}\right)$ tends to increase this condition of discomfort.

The representation of these indexes (mainly $E T, E T_{w}$ ) leads to the conclusion that the population of São Paulo (MRSP) suffers more from the cold than the hot, however, that conclusion could be influenced by the existence of a comfort zone unfit for the region, and that zone, should perhaps be below the standard set for the local population. A proper comfort zone for the region could be determined by a study where in addition to the measurements of all the variables involved between body and environment a questionnaire about the thermal sensations of the population was applied.

Regarding the indoor environment, the ET index also showed that there is a grant thermal discomfort within the city residences. As well as the outdoor environment, the ET index was representative of the condition experimented daily by the population of the São Paulo, and recorded high stress by cold, mainly during the winter (morning) and in other season alternating periods between comfortable and discomfortable feelings (during afternoons).

\section{ACKNOWLEDGEMENTS}

The authors thank the "Conselho Nacional de Desenvolvimento Científico e Tecnológico", CNPq, Brazil, for the support to carry out this work.

\section{REFERENCES}

ASHRAE/ANSI. 1992. Thermal environmental conditions for human occupancy. American Society of Heating, Refrigerating and AirConditioning Engineers, Standard 55, 52 pp.

BRAUN S. 2003. Influências meteorotrópicas nas doenças cardiovasculares na cidade de São Paulo-SP. Master dissertation, Instituto de Astronomia, Geofísica e Ciências Atmosféricas, Universidade de São Paulo, Brazil, 134 pp. 
FANGER PO. 1972. Thermal comfort. Analysis and applications in environmental engineering. McGraw-Hill Book Company, New York, 244 pp.

GILES BD, BALAFOUTIS C \& MAHERAS P. 1990. Too Hot for Comfort: The Heatwaves in Greece in 1987 and 1988. International Journal of Biometeorology, 34: 98-104.

GIVONI B. 1994. Passive and Low Energy Cooling of Buildings. Van Nostrand Reinhold, $267 \mathrm{pp}$.

GIVONI B. 1999. Minimum Climatic Information needed to Predict Performance of Passive Buildings in Hot Climates. In: PLEA'99, Brisbane Australia, pp. 197-202.

GIVONI B \& VECCHIA F. 2001. Predicting Thermal Performance of Occupied Houses. In: Conference on Passive and Low Energy Architecture, PLEA, 18., Florianópolis, Brazil.

GONÇALVES FLT, BRAUN S, DIAS PLS \& SHARVSY R. 2007. Influences of the weather and air pollutants on cardiovascular disease in the metropolitan area of São Paulo. Environmental Research, 104: 275-281.

HOUGHTEN FC \& YAGLOU CP. 1923. Determining of the comfort zone. Journal of American Heating and Ventilating Engineers, 29: 515-536.

KRÜGER E \& GIVONI B. 2003. Predicting thermal performance in occupied dwellings. Energy and Buildings, 36: 301-307.

KOENIGSBERGER OH, INGERSOLL TG, MAYHEW A \& SZOKOLAY SV. 1977. Viviendas y edifícios em zonas cálidas y tropicales. Paraninfo, Madrid, España, 329 pp.

MAIA JA. 2002. Uma análise do conforto térmico e suas relações meteorotrópicas na cidade de São Paulo-SP. Master dissertation, Instituto de Astronomia, Geofísica e Ciências Atmosféricas, Universidade de São Paulo, Brazil, 134 pp.

MISSENARD A. 1937. L'Homme et le climat. Paris: Librairie Plon. $270 \mathrm{pp}$.
MONTEIRO LM \& ALUCCI MP. 1996. A new thermal comfort index for urban design: the case of São Paulo, Brazil. Conference Reader, 33(1): 134-142.

MONTEIRO LM \& ALUCCI MP. 2005. Índices de conforto térmico em espaços abertos. Parte 1: Revisão histórica. In: Encontro Nacional 8.; Encontro Latino-Americano sobre Conforto no Ambiente Construído, 4., ENCAC/ENLACAC, Maceió, Alagoas, Brazil.

NAFSTAD P, JAAKKOLA JJ, SKRONALD A \& MAGNUS P. 2005. Day care center characteristics and children's respiratory health. Indoor Air, 15(2): 69-75.

OLGAY V. 1992. Design with climate. Bioclimatic Approach to Architectural Regionalism. New York: Van Nostrand Reinhold, 190 pp.

OLIVEIRA AP \& SILVA DIAS PL. 1982. Aspectos observacionais da brisa marítima em São Paulo. In: Congresso Brasileiro de Meteorologia, 2., Pelotas, RS, Brazil, pp. 129-145.

PAPST AL \& LAMBERTS R. 2001. Thermal Performance Evaluation of three Houses in Florianópolis, South of Brazil. In: The International Conference on Passive and Low Energy Architecture, 18., Florianópolis, Brazil, Paper Code PL01-144, pp. 7-9.

SUNDELL J. 1999. Indoor Environmentand Health. Stockholm, Sweden: National Institute of Public Health.

SUPING Z, GUANGLIN M, YANWEN W \& JI L. 1992. Study of the relationships between weather conditions and the marathon race, and of meteorotropic effects on distance runners. International Journal of Biometeorology, 36(2): 63-68.

THOM EC. 1959. The Discomfort Index. Weatherwise, 12: 57-60.

VIAMONT JCA. 1996. Environmental issues in the spontaneous settlement in Cochabamba. Instituto de Investigaciones de Arquitectura, Universidad Mayor de San Simón, Cochabamba, Bolivia, pp. 2-8.

Recebido em 16 janeiro, 2014 / Aceito em 10 abril, 2015

Received on January 16, 2014 / Accepted on April 10, 2015 


\section{NOTES ABOUT THE AUTHORS}

Anderson Spohr Nedel. Undergraduate in Meteorology from Universidade Federal de Pelotas (1999), master's in Remote Sensing from Universidade Federal do Rio Grande do Sul (2003) and Ph.D. in Meteorology from Universidade de São Paulo (2008). Currently, is Professor at the Meteorology Department at Universidade Federal de Pelotas. Has experience in Geosciences, meteorology, air pollution, and biometeorology acting on the human biometeorology, thermal comfort, human health, environmental monitoring and air quality.

Fábio Luiz Teixeira Gonçalves. Master's in Botany from Universidade de São Paulo (1990) and Ph.D. in Meteorology from Universidade de São Paulo (1997). Currently, is MS_5 level 3 Professor at the Universidade de São Paulo. Has experience in Geosciences, acting on the following subjects: numeric models, principal component analysis, epidemiology, air pollution and biometeorology.

Celso Macedo Junior. Undergraduate in Meteorology from Instituto de Astronomia, Geofísica e Ciências Atmosféricas from Universidade de São Paulo (USP). Currently, is mater's degree student at the School of Agricultural Engineering at Universidade Estadual de Campinas (FEAGRI/UNICAMP).

Maria Regina Alves Cardoso. Undergraduate in Odontology from Universidade de São Paulo (1979), master's in Public Health from Universidade de São Paulo (1990) and Ph.D. in Epidemiologia from University of London (1996). Currently, is Professor at the Epidemiology Department in the School of Public Health, Universidade de São Paulo. Has experience in Collective Health, focusing on Epidemiology, acting on the following subjects: children respiratory disease, environmental risk factors. 